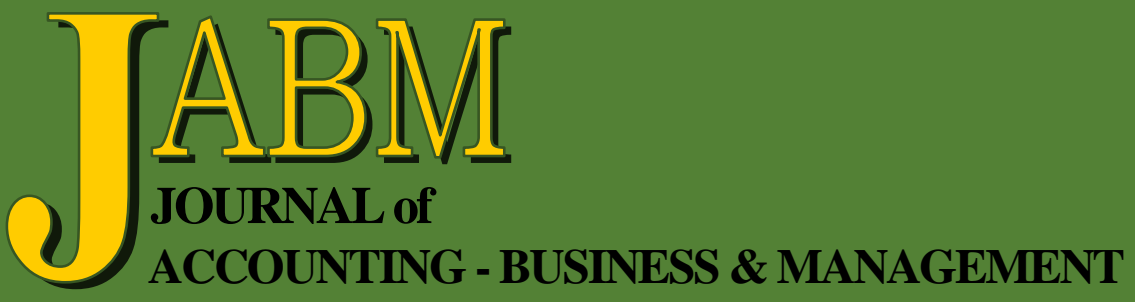

The Relationship between the Ownership Structure, Capital Structure and Performance

Ali Al-Thuneibat

The Effect of Self Efficacy and Information Quality on Behavioral Intention with Perceived Usefulness as Intervening Variable

Muslichah

Empirical Analysis of Factors Influencing Use of Internet on Ships

A. S. Saravanan, Jayalakshmy Ramachandran, A. Seetharaman, Karripur Nandakumar, and Capt. Kailash C. Joshi

Pawnshops Regulatory Environment: A Readability Analysis

Geralyn Miller, Steven A. Hanke, and Hui Di

Auditor Litigation and the Penalties on U.S. Client Firms after the Private Securities Litigation Reform Act

Nana Y. Amoah, Anthony Anderson, Isaac Bonaparte and Kyle Meyer 
Journal of Accounting - Business \& Management vol. 25 no. 1 (2018) 1-20

\title{
The Relationship between the Ownership Structure, Capital Structure and Performance
}

\author{
Ali Al-Thuneibat*
}

\begin{abstract}
This paper aims at providing an empirical evidence concerning the relationship between the ownership structure, capital structure and financial performance of the shareholding companies listed in Amman Stock Exchange (ASE). To measure the ownership structure, the researcher used four variables including foreign, institutional, managerial and concentrated ownership. The capital structure is measured by using the leverage, and the performance is measured by using the return on assets (ROA). To achieve the objectives of the study, a sample of 86 firms from the industrial and service companies listed in ASE during the period 2010 and 2014 is used. The results of the study showed that the relationship between ownership structure in general, and performance is positive and statistically significant, however, the results showed that the various types of ownership structure have different types of relationships with performance. More specifically, there is a negative impact of institutional and foreign ownerships on the performance and positive impact of concentrated and managerial ownerships. The results also revealed that there is a positive impact of the financial leverage on the relationship between ownership structure and firm performance. The findings of the study provide implications to the regulators, investors and managers in Jordan to take into consideration the environment-specific factors when developing corporate regulations and encourage concentrated and managerial ownership because they have positive impact on performance.
\end{abstract}

Keywords: ownership structure, concentrated ownership, managerial ownership, capital structure, performance, Amman Stock Exchange (ASE).

\section{INTRODUCTION}

Performance of business entities is continuously attracting the attention of researchers all over the world. Corporations are established and continuously governed and monitored to enable them achieve their objectives (Fama \& Jensen, 1983; Baysinger \& Hoskisson, 1990; Bathala \& Rao, 1995; Thomsen \& Pedersen, 2000; Cronqvist \& Nilsson, 2003; Hu \& Izumida, 2008; and Al-Najjar, 2015). Fama and Jensen (1983) stated that organizations compete for survival, and the form of organization that survives in an activity is the one that delivers the product demanded by customers at an acceptable price while covering costs.

Similarly, Jensen and Meckling (1976), stated that the basic objective of owners is to maximize their wealth, and they have to supervise the work of their agents and evaluate their performance. Therefore, researchers investigated corporate performance using many measures and various factors that influence it. Additionally, many research methodologies were used and many factors and roles were discussed. One of these

\footnotetext{
* Accounting Department, Faculty of Business, The University of Jordan-Business SchoolDepartment of Accounting, Amman-Jordan. E-mail: aaaldu@ju.edu.jo. This research was conducted during the sabbatical leave of 2016/2017 from the University of Jordan.
} 
factors or issues is the ownership structure. It is one of the basic issues connected with performance and intensively evaluated since 1930s.

The relationship between ownership structure and performance has received considerable attention by researchers all over the world (Chung et al., 2002; Kumar, 2003; Bjuggren et al., 2007; Hu \& Izumida, 2008; and Samiloglu \& Ulas, 2010). Ownership structure has received much attention because it is part of the agency theory and corporate governance. In Berle and Means (1932) investigated the role of corporate management and shareholders ownership in corporate performance. Jiang (2004) investigated the effect of ownership structure on the performance of listed companies in Heilongjiang Province. The results of the study showed that the different forms of ownership may have implications for corporate governance and performance of firms. Therefore the question which arises directly is, which structure of ownership is more efficient in improving company's performance?

At the same time the relationship between capital structure and performance has been under discussion and evaluation. Capital structure was used as a control variable in many situations where researchers investigated the factors influencing corporate performance (Adekunle, 2010; Margaritis \& Psillaki, 2010). Researchers also discussed the relationship between ownership structure and capital structure (Brailsford et al., 2002; Khamis et al., 2015). Ownership structure and capital structure are continuously receiving the attention of researchers all over the world because they are very related to and part of the agency and corporate governance (Khamis et al., 2015). The distribution of ownership and the sources of capital create a potential conflict and expected to be reflected on the various issues of an organization especially the performance. Agency theory highlights the expected conflict between management and shareholders. There is a conflict of interests among firms' managers, shareholders, and bondholders (Jensen \& Meckling, 1976). Brailsford et al. (2002) argued that the agency relationship between managers and shareholders has the potential to influence decision-making in the firm which in turn potentially impacts on firm characteristics such as value and leverage. Chow (1982) argued that researchers generally agree that, as the proportion of debt in a firm's capital structure increases, shareholders have a greater incentive to transfer wealth from the bondholders. This, in turn, implies a greater probability of suboptimal investment policies, and a greater potential gain to shareholders from contracting with the bondholders.

Fama and Jensen (1983) stated that the separation of "ownership" and "control" is a problem that has bothered students of corporations from Adam Smith to Berle and Means and Jensen and Meckling. Accordingly, this study tries to be distinguished by its concentration on all these factors in one research because they are very related to each other, therefore this study will concentrate on the relationship between ownership structure, capital structure and performance. This is the first study in Jordan that takes into account the interplay between the various types of ownership structure, and capital structure as determinants of performance. The findings of the study showed that there is a negative impact of institutional and foreign ownerships on the financial performance and positive impact of concentrated and managerial ownerships. The results also have revealed that there is a positive impact of the financial leverage on the relationship between ownership structure and firm's financial performance.

The rest of the study is organized as follows. The researcher starts with providing the readers an insight into the different existing theories and reviewing related previous literature on the relationship between ownership structure, capital structure and performance on which the hypotheses were developed. Then the study 
methodology is introduced including the study sample and period, the variables under examination, and models of the study. The final part of the study reports the empirical results and conclusions of the study.

\section{LITERATURE REVIEW AND HYPOTHESES DEVELOPMENT}

\subsection{Ownership Structure and Performance}

Ownership structure is defined as the allocation of ownership according to the voting rights and corporate capital. It also refers to the identity of shareholders (Jensen \& Meckling, 1976). Ownership structure plays an important role in corporate governance as being one of the basic control mechanisms over agency costs (Kumar, 2003). Hu and Izumida (2008) stated that ownership structure is often thought as an important instrument for corporate governance to resolve the conflict of interests between shareholders and managers. Researchers concentrated on ownership structure as one of the important elements when investigating the role of corporate governance in various corporate issues (Bushee, 1998; Chung et al., 2002; Bjuggren et al., 2007; and Zhang, 2017). Those researchers, argue, for example, that the expert owners play an important role in monitoring the activities of the management and the accounting policies used by the management in preparation and presentation of the financial statements.

However, Hu and Izumida (2008) stated that although the ownershipperformance relationship has been a hot topic for decades, scholars have not reached an agreement with it. They added that this topic is subject to controversy in theory, therefore, empirical research becomes more important to examine. Hu and Izumida (2008) added that the existing evidence fails to establish a convincing link between ownership structure and corporate performance because of the diversity of influences and factors related to this issue including environmental, political, cultural and economic influences.

Jiang (2004) argued that because ownership structure has links with corporate governance, it can have both positive and negative effects on corporate governance and performance of firms. For example, Asadi and Bahlevan (2016) stated that there is a positive relationship between the various types of ownership structure and performance measured by ROA, return of equity (ROE), market to book value (MBV) and market value added (MVA). Additionally, Rahmani et al. (2010), found that the companies which their major shareholders are the quasi-governmental public groups, have better performance than others.

On the other hand, Bjuggren et al. (2007) stated that ownership structure has a negative effect on company's performance. Similarly, Khamis et al. (2015) found that ownership concentration had a negative effect on performance with statistical significance. The relation between managerial ownership and performance was positive but not statistically significant. The study found that there is a positive relationship between institutional ownership and performance. A negative relationship with statistical significance between foreign ownership and performance in Bahraini companies was also found.

As appears from the results of some previous research mentioned in this introduction, empirical evidence showed contradicting conclusions based on differences in environments and the types of ownership structure, that is, some of them point to the positive relationship and others negative relationship. Therefore, the following sections will discuss the relationship between performance and the various types of ownership structure. 


\subsection{Institutional Ownership and Performance}

Individuals and institutions' abilities and experiences regarding monitoring and controlling the activities of the companies and their management vary, however, institutional investments enhance the controlling process over management decisions and leads to performance improvements (Al-Najjar, 2015). Additionally, some researchers (Wan, 1990) found a positive effect of institutional ownership on firms' values. Bargezar and Babu (2008) investigated the relationship between ownership structure in terms of institutional and non-institutional ownership and performance in terms of return on asset, return on equity, and Tobin's Q. They stated that there is a positive relationship between institutional ownership and firm performance. Similarly, Kordlor et al. (2010) found a significant positive relationship between institutional ownership (both active and passive) and the company's performance.

Demsetz and Villalonga (2001) found that ownership and performance affect each other in various ways. They stated that firms which are highly concentrated practice better monitoring and reduce the potential entrenchment of managers. Similarly, Yuan et al. (2008) stated that the institutional ownership enhances good corporate governance, therefore improves firm's performance. Institutional owners have more incentives and ability to monitor management because they have superior ability to monitor mangers at lower transaction costs. Chen et al. (2008) and Fazlzadeh et al. (2011) indicated that there is a positive relationship between institutional ownership and firm performance measured by return on equity.

On the other hand, Al-Najar (2015) investigated whether institutional ownership affects the firm's performance in Jordan. Firm's performance is measured using ROA and ROE. The results of the study indicated that there is no strong evidence that there is a relationship between both institutional ownership and firm's performance for Jordanian listed firms. Similarly, Matanda et al. (2015) stated that there is no relationship between institutional ownership and performance of commercial banks in Kenya when ROE, ROA and TBQ were used as performance measures and that bank size has a moderating effect on this relationship.

\subsection{Foreign Ownership and Performance}

Foreign ownership is characterized by its geographic distance from corporate managements, which increases the management freedom in carrying the activities of the company in a manner that stresses their own interests. Gurbuz and Aybars (2010) stated that many scholars have recently been investigating the relationship between foreign ownership and the performance of the firm because of the increase in the amount of overseas investment in the world economy. However, their study revealed that minority foreign-owned companies perform better than domestic ones in terms of operating profitability and when return on assets is employed as a performance measure. Additionally, Boardman et al. (1997) stated that firms with foreign ownership out-perform domestically owned firms with similar characteristics. The foreign ownership improves firm's financial performance in Turkey up to a certain level, beyond which additional ownership by the foreigners does not add to firm profitability.

Similarly, In Turky, the findings of Gunduz and Tatoglu (2003) revealed that the ROA of foreign owned firms is significantly better than the ROA of domestic firms. Moreover, Gedajlovic et al. (2005) asserted that foreign ownership, is positively and significantly related to dividend payout. Moreover, Musallam (2015) examined the impact of ownership structures including foreign ownership on corporate 
performance using a panel data from Malaysia listed companies over a period of 2000 to 2009 . He concluded that the impact of foreign ownership is positive and significant on corporate performance.

However, in the USA, Kim and Lyn (1990) stated that domestic firms are more profitable in terms of return on equity after taxes. Moreover, Konings (2001) study revealed that foreign firms do not perform better than domestic ones. Similarly, Chari et al. (2009) examined the relationship between foreign ownership and firms' performance in the United States. The results of their study suggest that, in the years following the acquisition, sales and employment decline while profitability rises.

Furthermore, Viet (2013) investigated the relationship between foreign ownership and firm's performance in emerging countries. The results of the study showed that there is a significant inverted $U$ shaped relationship between foreign ownership and firm performances. Furthermore, he found that foreign investors disfavor firms with high concentration of ownership that relates to image of weak corporate governance and that foreign investors are likely to invest in firms with good financial performances.

\subsection{Concentrated Ownership and Performance}

Ownership structure is classified as concentrated and dispersed; it is considered concentrated when small number of shareholders own a significant proportion of shares issued by the company (Sheikh et al., 2013). They argued that blockholders are probably to be more effective in monitoring management than small shareholder (dispersed ownership) since blockholders have essential investment and significant voting power to protect their investments. Gillan and Starks (2003) indicated that when ownership is concentrated, the agency conflict among managers and shareholders is minimized.

Many researchers stated that ownership concentration has a positive relationship with corporate performance (Leech \& Leahy, 1991; Xu \& Wang, 1999; Thomsen \& Pedersen, 2000; Denis \& McConnell, 2003; Kapopoulos \& Lazaretou, 2007; Perrini et al., 2008; Mandac1 \& Gumus, 2010; Sheikh et al., 2013; Khamis et al., 2015; and Saleh et al., 2017). These researchers stated that ownership concentration may constrain managerial diversion from shareholder interests and enhance the power of shareholders against the power of managers and therefore the value of the firm and its profitability.

On the other hand some studies (Demsetz, 1983; Demsetz \& Lehn, 1985; Demsetz \& Vilalonga, 2001; Kumar, 2003; and Ben Ali \& Lesage, 2016) found that there is no significant relationship between concentrated ownership and company value. These researchers argued that a diffused ownership structure enhances the value of a corporate entity while a single ownership is not enough to maximize the value of a firm. Researchers expected that the existence of concentrated ownership will increase the conflict between blockholders and minority.

Fazlzadeh et al. (2011) argued that internal stakeholders (managers and employees) will be discouraged from costly investing and major shareholders will have the incentives to use their control to obtain their specific interests. Fan and Wong (2005) highlights that the existence of blockholders raises the risk of self-serving behavior and thus a good control mechanism should be implemented to protect the interest of minatory shareholders. Therefore, researchers (Slovin \& Sushka, 1993; Cronqvist \& Nilsson, 2003) find a non-linear relationship between ownership concentration and firm performance or negative impact. They found that the greater 
dispersion of ownership the higher is valuation ratio, profit margin, and growth rate of net assets, depending upon control type.

However, researchers argued that dispersed ownership is most common in developed countries and concentrated ownership is most common in developing countries. Al-Haddad et al. (2011) found that the ownership of Jordanian companies is characterized by a high degree of concentration, which is expected to play an important role in governing the corporate activities and this will be reflected on the performance of the corporation. Similarly, Nadia (2004) found that there is a high concentration of ownership in Jordanian banks but she stated that this did not affect performance. On the other hand, Jaafar and El-Shawa (2009) examined the influence of ownership concentration on performance in Jordan and found that the ownership concentration, has a significant and positive relationship with performance.

\subsection{Managerial Ownership and Performance}

The prevalent role of corporate governance reflected in the accounting and finance literature is the agency view (Fama \& Jensen, 1983; Baysinger \& Hoskisson, 1990; and Bathala \& Rao, 1995). Hu and Izumida (2008) argued that the central premise of the theory is that self-interested agents can engage in decision making and behaviors that may be inconsistent with maximizing value of the principals. Achchuthan and Kajananthan (2013) indicated that in order to solve conflict of interest between managers and shareholders, agency theorists suggest that top management should have a considerable ownership of the company.

Jensen and Meckling (1976) stated that managerial ownership is an important medium for reducing agency conflict, that is, the increase in managerial ownership is expected to increase the probability of reducing management manipulations to satisfy their own interests, which in turn direct the management attention to the company's performance in the long run. They proposed that a high level of managerial ownership helps in reducing the conflict between managers and shareholder, which is expected to lead to peter performance. Similarly, other researchers (Li et al., 2007; Nelson \& Mohamed-Rusdi, 2015) argued that managerial ownership reduces conflict of interests and therefore enhances the efficiency of management shareholders in doing their job effectively which will improve the performance of the company.

However, other researchers (Demsetz, 1983; Fama \& Jensen, 1983) argued that the firm will be less valuable when managers with a significant equity have enough voting power to pursue their own interests and avoid outside checks. Perrini et al. (2008) also found that managerial ownership does not represent a mechanism of reducing agency costs when there is a concentrated ownership. Based on these theoretical arguments we state the following hypotheses:

$\mathbf{H}_{01}$ : there is no statistical significant impact of the ownership structure on the performance of the shareholding companies in Jordan.

$\mathbf{H}_{011}$ : there is no statistical significant impact of the institutional ownership on the performance of the shareholding companies in Jordan.

$\mathbf{H}_{012}$ : there is no statistical significant impact of the foreign ownership on the performance of the shareholding companies in Jordan.

$\mathbf{H}_{013}$ : there is no statistical significant impact of the ownership concentration on the performance of the shareholding companies in Jordan.

$\mathbf{H}_{014}$ : there is no statistical significant impact of the managerial ownership on the performance of the shareholding companies in Jordan. 


\subsection{Ownership Structure, Capital Structure and Performance}

Agency costs arise because shareholders face problems in monitoring management. To reduce agency costs and solve many of agency problems, various corporate governance mechanisms are designed. Morck et al. (2005) stated that there are two obvious consequences for corporate governance. On the one hand, dominant shareholders have both the incentive and the power to discipline management.

On the other hand, concentrated ownership can create conditions for a new problem, because the interests of controlling and minority shareholders are not aligned. Additionally, King and Santor (2007) argued that the relationship between ownership and capital structure described to be either at higher or lower levels depending on many factors including the manager's risk aversion, the costs of monitoring and bankruptcy, the threat of takeovers, and the growth opportunities of the firm. Furthermore, Moghadam and Jafari (2015), stated that the financial leverage has a significant positive relationship with the performance, that is, firms with higher debt levels are more profitable. Similarly, Brenda (2014) found that debt ratio and firms' size are the determinants of firms' performance and assets tangibility and ownership concentration are the determinants of firms' capital structure. He added a high debt ratio increases firm's value by constraining managers to act more in the interest of shareholders (Berger \& Bonaccorsi di Patti, 2006; Brenda, 2014).

Brailsford et al. (2002) investigated the relationship between ownership structure and capital structure using the agency framework. They concluded that the distribution of equity ownership among corporate managers and external block holders may have a significant relation with leverage. They added that there is a positive relation between external block holders and leverage, and non-linear relation between the level of managerial share ownership and leverage. Their results also suggest that the relation between external blockholders ownership and leverage varies across the levels of managerial share ownership.

Hsu (2013) investigated the effects of leverage and ownership structure as moderating effects between $\mathrm{RD}$ expenditures and firm performance. The results showed that the leverage has a negative effect on the relationship between RD and firm performance. He argues that studies have found that investors with large ownership serve a monitoring role in reducing manager's prejudiced behavior. The sophistication of ownership structure allows managers to focus on long-term return rather than on short-term earnings. Others argue that that the recurrent trading and short-term focus of institutional investors encourage management to engage in prejudiced investment behavior.

Adekunle (2010) examined the impact of capital structure on firm's financial performance using a sample of thirty non- financial firms listed on the Nigerian Stock Exchange during the period, 2001-2007. Panel data for the selected firms are generated and analyzed using Ordinary Least Squares (OLS) as a method of estimation. The result showed that a firm's capital structure surrogated by Debt Ratio, has a significant negative impact on the firm's financial performance.

However, Boroujeni et al. (2013) examined the effect of capital structure and ownership structure on Firm's performance. The research results show that capital structure and ownership structure have a positive impact on the performance of companies listed on Tehran Stock Exchange. Similarly, Kajananthan and Nimalthasan (2013) argued that Gross profit margin and return on equity are significantly correlated with debt assets ratio, and the increase in leverage negatively affects the return on equity. They recommended managers to achieve the optimal capital structure level to 
maximize the firms' performance, that is, adopting an appropriate mix of capital structure in order to increase the profitability, managements should finance their projects with retained earnings and use leverage as a last option. It appears from this discussion that the relationship between capital structure, ownership structure and performance need more investigation within the specific context of the phenomenon, therefore this study will investigate the following hypotheses:

$\mathbf{H}_{\mathbf{0 2}}$ : there is no statistical significant impact of the capital structure on the relationship between ownership structure and the performance of the shareholding companies in Jordan.

$\mathbf{H}_{021}$ : there is no statistical significant impact of the capital structure on the relationship between institutional ownership and the performance of the shareholding companies in Jordan.

$\mathbf{H}_{\text {022: }}$ : there is no statistical significant impact of the capital structure on the relationship between foreign ownership and the performance of the shareholding companies in Jordan.

$\mathbf{H}_{\mathbf{0 2 3}}$ : there is no statistical significant impact of the capital structure on the relationship between concentrated ownership and the performance of the shareholding companies in Jordan.

$\mathbf{H}_{024}$ : there is no statistical significant impact of the capital structure on the relationship between managerial ownership and the performance of the shareholding companies in Jordan.

\section{RESEARCH METHODOLOGY}

This study investigates the relationship between the ownership structure and the performance of the shareholding companies in Jordan and the effects of capital structure on this relationship. Ownership structure has the capability to encourage the invested companies to pursue the profitable projects. Additionally, leverage as a measure of capital structure is important for a firm to ensure the financial resources required achieve the objectives of the company and improve performance. Therefore, this study addresses the effect of leverage on the relationship between ownership structure and performance. To achieve the objectives of the study this section discusses the study population and sample, defines the study variables, and designs the research model.

\subsection{Study Population and Sample}

The study population include all industrial and service companies listed on Amman Stock Exchange (ASE) for the period from 2010 to 2014. The reason behind selecting non-financial companies and excluding the financial companies referred to the highly regulated environment applicable to financial sector. As well, the reason behind choosing the study period from 2010 to 2014 was referred to the availability of the data on the website of Amman Stock Exchange to these companies for the most recent five years (2010-2014). The study sample consisted of 86 companies from the industrial and service companies. In order to include the company in the study sample, required data to calculate all study variables should be available for the study periods. A sample of 86 companies out of 123 companies (the study population) met the required criterion.

\subsection{Limitations of the Study}

This study is delimited to the industrial and service companies listed in Amman Stock Exchange. The financial sector was excluded because of; the specific regulations 
related to it, the specific governance requirements, complexity and high risk. The other limitation is related to the calculation of the managerial ownership, that is, we used board of directors ownership because of unavailability of data related to all managers. The study also covered only five years because of the difficulty of obtaining the data related to some types of ownership.

\subsection{Model Specification}

In order to test the study hypotheses two models were used. The first one depicts the relationship between performance measured by the ROA and the various types of ownership. The second model depicts the relationship between performance measured by the ROA and the various types of ownership and the capital structure measured by the leverage:

Model 1:

$\mathrm{PF}=\alpha+\beta_{1} \mathrm{INST}+\beta_{2}$ FOREIGN $+\beta_{3}$ BLOCK $+\beta_{4}$ MNAGERIA $+\beta_{5}$ LNASSET $+\beta_{6} \beta_{9} \mathrm{IND}+\varepsilon$

Model 2:

PF $=\alpha+\beta_{1}$ INST $+\beta_{2}$ FOREIGN $+\beta_{3}$ BLOCK $+\beta_{4}$ MNAGERIAL $+\beta_{5}$ LNASSET $+\beta_{6} \mathrm{IND}+\beta_{7} \mathrm{LEV}+\varepsilon$

\begin{tabular}{ll}
\hline \multicolumn{1}{c}{ Variable } & \multicolumn{1}{c}{ Definition and Measurement } \\
\hline PF & $\begin{array}{l}\text { Firm performance measured by ROA. } \\
\text { Institutional ownership measured as the percentage of the shares held } \\
\text { by institutional investors. }\end{array}$ \\
FOREIGN & $\begin{array}{l}\text { Foreign ownership measured by the percentage of the shares held by } \\
\text { foreign investors. }\end{array}$ \\
BLOCK & $\begin{array}{l}\text { Concentrated Ownership is large shareholder ownership measured by } \\
\text { the percentage company's shares owned by large shareholders. }\end{array}$ \\
TNAGERIAL & $\begin{array}{l}\text { The managerial ownership measured by the percentage of company's } \\
\text { shares owned by executive directors and their families. }\end{array}$ \\
AND & $\begin{array}{l}\text { An indicator dummy variable equals one if the firm operates in } \\
\text { industrial sector and zero otherwise. } \\
\text { Leverage measured as the ratio of total debt to total assets. }\end{array}$ \\
\hline
\end{tabular}

\section{ANALYSIS AND RESULTS DISCUSSION}

\subsection{Descriptive Statistics}

Table 1 presents some descriptive statistics for the study variables of 86 Jordanian companies and 424 firm- year observations listed on ASE during the period (2010-2014). This table shows the means and standard deviations of the dependent and independent variables included in the regression model.

Table 1

Descriptive Statistics for the Variables

\begin{tabular}{lccccc}
\hline & N & Min. & Max. & Mean & Std. Deviation \\
\hline ROA & 424 & -0.236 & 0.323 & 0.03520 & 0.081153 \\
INST & 424 & 0.000 & 1.000 & 0.49921 & 0.277334 \\
FOREIGN & 424 & 0.000 & 0.988 & 0.19055 & 0.242354 \\
BLOCK & 424 & 0.000 & 0.999 & 0.60835 & 0.217625 \\
MNAGERAL & 424 & 0.002 & 0.999 & 0.51013 & 0.252317 \\
LNASSET & 424 & 13.060 & 21.292 & 17.02928 & 1.503536 \\
LEV & 424 & 0.000 & 0.953 & 0.30322 & 0.206379 \\
\hline Valid N (list wise) & 424 & & & \\
\hline
\end{tabular}


The table shows that the ROA ranges between -0.236 and 0.323 with a mean of 0.3520. However, although the minimum value of the ROA is negative, the observations show that only very small number of the companies suffer from a loss, which indicates that the sample companies over the study period have a relatively good financial performance. Furthermore, the table shows that the mean of each type of the ownership is nearly $50 \%$ or more except for the foreign ownership which shows low mean (0.19). However, the mean of the concentrated ownership is relatively high and it represents the highest mean from all types of ownership, that is, the mean is 0.60835 . This results supports the results of previous studies in Jordan (Nadia, 2004; Al-Haddad et al., 2011) who stated that the ownership of Jordanian companies is characterized by a high degree of concentration. The table also shows that the financial leverage is on average 0.30322 which indicates that approximately, 30\% of the capital structure of the industrial and service companies in Jordan, is contributed by debts.

\subsection{Correlation Analysis}

As appears from Table 2 the correlation coefficients between ROA and various types of ownership range between -0.02 and 0.177 , which means that there are different levels of correlation between the ROA and the Ownership structure. That is, the relationship between institutional ownership and ROA is weak and insignificant because the correlation coefficient is 0.056 and the significance is 0.254 . Similarly, the relationship between foreign ownership and ROA is weak and insignificant because the correlation coefficient is -0.020 and the significance is 0.683 .

However, the relationship between the managerial ownership and ROA which is, although it is low, it is significant at a level of 0.01. Additionally, the table shows that the relationship between the concentrated ownership and ROA which is, although it is low, it is significant at a level of 0.01 .

The table also shows that there is a relationship between institutional ownership and other types of ownership. As appears from the table there is a significant relationship between institutional ownership and foreign ownership with a correlation coefficient of 0.409 . The table also shows that there is a significant relationship between institutional ownership and concentrated ownership with a correlation coefficient of 0.423 , and there is a significant relationship between institutional ownership and managerial ownership with a correlation coefficient of 0.499 . However, what attracts the attention is the relationship between managerial ownership and concentrated ownership which is significant with a correlation coefficient of 0.719 .

The table also shows that there is a negative relationship between ROA and Leverage, that is, the correlation coefficient is -0.10 but it is significant. It appears from the table also that the relationship between leverage and institutional ownership is the strongest among other types of ownership, that is, the correlation coefficient is 0.176 and it is positive and significant. The table shows that the lowest relationship is between leverage and foreign ownership, that is, the correlation coefficient is 0.04 and insignificant. However, the relationship between leverage and concentrated ownership is negative, that is the correlation coefficient is -0.12 and significant and between leverage and managerial ownership is also negative, that is, the correlation coefficient is -0.12 and significant. This means that the relationship between ownership structure and capital structure of the shareholding companies in Jordan varies depending on the type of the ownership. 
Table 2

Pearson Rank Correlations for the Variables

\begin{tabular}{lcccccccc}
\hline & ROA & INST & FOREIG & BLOCK & MNAG. & LNAS & INDUS & LEV \\
\hline \multirow{2}{*}{ ROA } & 1 & .056 & -.020 & $.100^{*}$ & $.177^{* *}$ & $.380^{* *}$ & $-.136^{* *}$ & $-.101^{*}$ \\
\multirow{2}{*}{ INST } & .056 & .254 & .683 & .039 & .000 & .000 & .005 & .037 \\
& .254 & 1 & $.409^{* *}$ & $.423^{* *}$ & $.499^{* *}$ & $.320^{* *}$ & -.067 & $.176^{* *}$ \\
FOREIG & -.020 & $.409^{* *}$ & .000 & .000 & .000 & .000 & .168 & .000 \\
& .683 & .000 & 1 & $.288^{* *}$ & $.317^{* *}$ & $.260^{* *}$ & -.004 & .042 \\
BLOCK & $.100^{*}$ & $.423^{* *}$ & $.288^{* *}$ & .000 & .000 & .000 & .938 & .386 \\
\multirow{2}{*}{ MNAG. } & .039 & .000 & .000 & 1 & $.719^{* *}$ & .074 & $-.171^{* *}$ & $-.123^{*}$ \\
& $.177^{* *}$ & $.499^{* *}$ & $.317^{* *}$ & $.719^{* *}$ & .000 & .126 & .000 & .011 \\
LNAS & .000 & .000 & .000 & .000 & 1 & $.288^{* *}$ & -.091 & $-.120^{*}$ \\
& $.380^{* *}$ & $.320^{* *}$ & $.260^{* *}$ & .074 & $.288^{* *}$ & .000 & .062 & .014 \\
INDUS & .000 & .000 & .000 & .126 & .000 & 1 & $-.204^{* *}$ & $.390^{* *}$ \\
& $-.136^{* *}$ & -.067 & -.004 & $-.171^{* *}$ & -.091 & $-.204^{* *}$ & .000 & .000 \\
LEV & .005 & .168 & .938 & .000 & .062 & .000 & 1 & $-.103^{*}$ \\
& $-.101^{*}$ & $.176^{* *}$ & .042 & $-.123^{*}$ & $-.120^{*}$ & $.390^{* *}$ & $-.103^{*}$ & .033 \\
& .037 & .000 & .386 & .011 & .014 & .000 & .033 & 1 \\
\hline
\end{tabular}

${ }^{*}$ Correlation is significant at the 0.05 level (2-tailed), and

** Correlation is significant at the 0.01 level (2-tailed).

a. Hypotheses Testing

Testing the first model and the first hypothesis:

PF $=\alpha+\beta_{1}$ INST $+\beta_{2}$ FOREIGN $+\beta_{3}$ BLOCK $+\beta_{4}$ MNAGERIAL $+\beta_{5}$ LNASSET $+\beta_{6} \beta_{9} I N D+\varepsilon$

As a first step in regression analysis we need to check for the multicollinearity among the explanatory variables of the first model. The Pearson correlation coefficients between explanatory variables as shown in Table 2 above range between 0.02 and 0.71 , which means that all correlation coefficients are less than 0.8 or 0.90 , therefore, we conclude that there is no any indication of multicollinearity among the explanatory variables (Field, 2005; Hair et al., 2010; and Pallant, 2010). However, to be more certain a further test is implemented by calculating the variance inflation factors (VIF). According to (Field, 2005; Gujarati, 2009), multicollinearity problem exists when the values of the tolerance factor is closer to zero and variance inflation factor less than 10. Table 3 shows that (VIF) values range from (1.097) to (2.492) and the tolerance level ranges from (0.401) to (0.912). Hence, no signs of multicollinearity in the first model.

Table 3

Collinearity Statistics for the Independent Variables in Model 1

\begin{tabular}{|c|c|c|}
\hline \multirow{2}{*}{ Model } & \multicolumn{2}{|c|}{ Collinearity Statistics } \\
\hline & Tolerance & VIF \\
\hline (Constant) & & \\
\hline INST & 0.651 & 1.536 \\
\hline FOREIGN & 0.789 & 1.267 \\
\hline BLOCK & 0.430 & 2.328 \\
\hline MNAGERAL & 0.401 & 2.492 \\
\hline LNASSET & 0.766 & 1.306 \\
\hline INDUSTRY & 0.912 & 1.097 \\
\hline
\end{tabular}

The model summary in Table 4 shows some statistics related to the relationship between ownership structure and ROA. The table shows that the correlation between ownership structure and ROA is 0.426 , which means that there is a positive relationship between them. 
Table 4

Model Summary for the Variables in Model 1

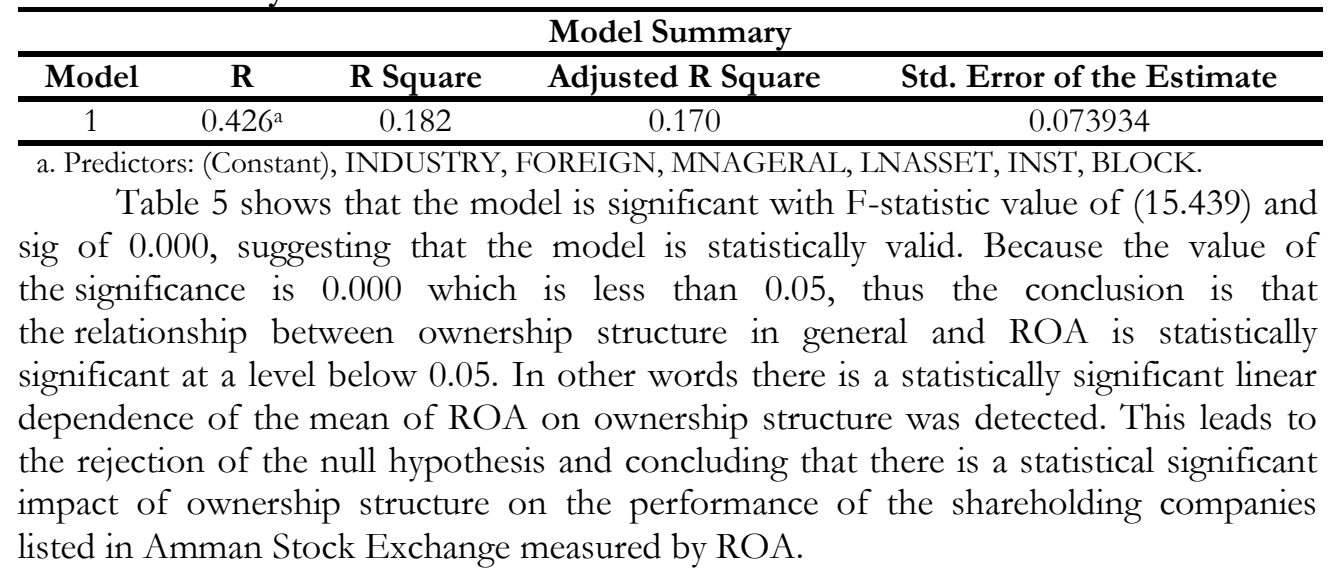

Table 5

ANOVA Results for the Variables in Model 1

\begin{tabular}{llccccc}
\hline \multicolumn{7}{c}{ ANOVA $^{\mathrm{a}}$} \\
\hline & Model & Sum of Squares & Df & Mean Square & F & Sig. \\
\hline \multirow{3}{*}{1} & Regression & 0.506 & 6 & 0.084 & 15.439 & $.000^{\mathrm{b}}$ \\
\cline { 2 - 7 } & Residual & 2.279 & 417 & 0.005 & & \\
\cline { 2 - 7 } & Total & 2.786 & 423 & & & \\
\hline
\end{tabular}

a Dependent variable: ROA, and

b Predictors: (Constant), INDUSTRY, FOREIGN, MNAGERAL, LNASSET, INST, BLOCK.

In order to test the sub-hypotheses of the first hypothesis Table 6 shows the regression coefficients for each type of ownership. The regression coefficient for institutional ownership is (-0.102), and the significance value is $(0.065)$, which is higher than the significance level used in this research (0.05), therefore the effect of institutional ownership on ROA is negative and insignificant. Accordingly, we accept the first null sub-hypothesis and conclude that there is no significant statistical impact of institutional ownership on performance measured by ROA. This conclusion is incongruent with (Ongore, 2011; Khamis et al., 2015) who found that institutional ownership has a significant positive relationship with firm performance. However, AlNajjar (2015) found that there is no strong evidence that there is a relationship between both institutional ownership and firm performance for Jordanian listed firms.

Insert Table 6 here

The regression coefficient for foreign ownership is (-0.137), and the significance value is (0.006), therefore the effect of foreign ownership on ROA is negative and significant. Accordingly, we reject the second null sub-hypothesis and conclude that there is a significant statistical impact of foreign ownership on performance measured by ROA. Our result is consistent with other studies (Khamis et al., 2015) in Bahrain who found that a negative relationship with statistical significance between foreign ownership and performance in Bahraini companies was found. However, other studies (Gurbuz \& Aybars, 2010; Ongore, 2011; and Musallam, 2015) indicated that the foreign ownership improves firms' financial performance and has a positive and significant impact on corporate performance.

The regression coefficient for the concentrated ownership is (0.078), and the significance value is (0.247), therefore the effect of concentrated ownership on ROA is positive but insignificant. Accordingly, we accept the null sub-hypothesis and 
conclude that there is no significant statistical impact of concentrated ownership on performance measured by ROA. This conclusion is consistent with (Sheikh et al., 2013) who found a positive relationship between ownership concentration and performance. Sheikh et al. (2013) stated that this will improve the effective monitor over management and will result in enhancement of the value of the firm. However, this conclusion is inconsistent with some previous studies (Ongore, 2011; Khamis et al., 2015) who found that ownership concentration has a significant negative relationship with firm performance.

\section{Table 6}

Regression Results for Model 1 and the Collinearity Statistics for the Independent Variables

\begin{tabular}{|c|c|c|c|c|c|c|c|}
\hline \multicolumn{8}{|c|}{ Coefficients $^{\mathrm{a}}$} \\
\hline \multirow{2}{*}{ Model } & \multicolumn{2}{|c|}{$\begin{array}{c}\text { Unstandardized } \\
\text { Coefficients }\end{array}$} & \multirow{2}{*}{$\begin{array}{c}\begin{array}{c}\text { Standardized } \\
\text { Coefficients }\end{array} \\
\text { Beta }\end{array}$} & \multirow[t]{2}{*}{$\mathrm{t}$} & \multirow{2}{*}{ Sig. } & \multicolumn{2}{|c|}{$\begin{array}{c}\text { Collinearity } \\
\text { Statistics }\end{array}$} \\
\hline & B & Std. Error & & & & Tolerance & VIF \\
\hline (Constant) & -0.346 & 0.048 & & -7.198 & 0.000 & & \\
\hline INST & -0.030 & 0.016 & -.102 & -1.852 & 0.065 & 0.651 & 1.536 \\
\hline FOREIGN & -0.046 & 0.017 & -.137 & -2.739 & 0.006 & 0.789 & 1.267 \\
\hline BLOCK & 0.029 & 0.025 & .078 & 1.160 & 0.247 & 0.430 & 2.328 \\
\hline MNAGERAL & 0.030 & 0.022 & .094 & 1.339 & 0.181 & 0.401 & 2.492 \\
\hline LNASSET & 0.022 & 0.003 & .408 & 8.053 & 0.000 & 0.766 & 1.306 \\
\hline INDUSTRY & -0.006 & 0.008 & -.038 & -0.827 & 0.409 & 0.912 & 1.097 \\
\hline
\end{tabular}

${ }^{a}$ Dependent variable: ROA.

The regression coefficient for the managerial ownership is (0.094), and the significance value is (0.181), therefore the effect of managerial ownership on ROA is positive but insignificant. Accordingly, we accept the null hypothesis and conclude that there is no significant statistical impact of managerial ownership on performance measured by ROA. This result is consistent with Ongore (2011) who found that managerial ownership has significant positive relationships with firm performance. This results also agrees with (Jensen \& Meckling, 1976) who suggested that increases in fraction of equity owned by managers might result in alignment the interests of the managers with the interest of other shareholders and might mitigate losses. However, it is inconsistent with (Khamis et al., 2015) who found that Managerial ownership does not have positive effect on performance except in the situation when ownership concentration declines, It is also inconsistent with (Sheikh et al., 2013) who argued that managers tend to use a firm's resources for their personal benefits, which in turn negatively influences performance.

Testing the second model and the second hypothesis:

PF $=\alpha+\beta_{1}$ INST $+\beta_{2}$ FOREIGN $+\beta_{3}$ BLOCK $+\beta_{4}$ MNAGERIAL $+\beta_{5}$ LNASSET $+\beta_{6} \mathrm{IND}+\beta_{7} \mathrm{LEV}+\varepsilon$

As mentioned above, the first step in regression analysis is to check for the multicollinearity among the explanatory variables. The Pearson correlation coefficients between explanatory variables as shown in Table 2 above range between 0.02 and 0.71 , which means that all correlation coefficients are less than 0.8 or .90 Additionally, Table 7 shows that the values of (VIF) range from (1.098) to (2.654) and the tolerance level ranges from (0.377) to (0.911). Hence, no signs of multicollinearity in the second model. 
Table 7

Collinearity Statistics for the Independent Variables in Model 2

\begin{tabular}{lcc}
\hline \multicolumn{1}{c}{ Model } & \multicolumn{2}{c}{ Collinearity Statistics } \\
\cline { 2 - 3 } (Constant) & & VIF \\
\hline INST & 0.622 & 1.607 \\
FOREIGN & 0.787 & 1.271 \\
BLOCK & 0.430 & 2.328 \\
MNAGERAL & 0.377 & 2.654 \\
LNASSET & 0.647 & 1.545 \\
LEV & 0.752 & 1.329 \\
INDUSTRY & 0.911 & 1.098 \\
\hline
\end{tabular}

The model summary in Table 8 shows some statistics related to the relationship between ownership structure, capital structure and ROA. The table shows that the correlation between ownership structure, capital structure and ROA is 0.496, which means that there is a positive relationship between them. It appears that the correlation increased in comparison with what mentioned before. That is the effect of the capital structure on the relationship between ownership structure and performance is positive, therefore the regression coefficient increased from 0.426 to 0.496 .

Table 8

Model Summary for the Variables in Model 2

\begin{tabular}{ccccc}
\hline \multicolumn{5}{c}{ Model Summary } \\
\hline Model & $\mathbf{R}$ & R Square & Adjusted R Square & Std. Error of the Estimate \\
\hline 2 & $0.496^{\mathrm{a}}$ & 0.246 & 0.233 & 0.071059 \\
\hline a Predictors: (Constant) & INDUSTRY, FOREIGN, LEV, MNAGERAL, LNASSET, INST, BLOCK.
\end{tabular}

a Predictors: (Constant), INDUSTRY, FOREIGN, LEV, MNAGERAL, LNASSET, INST, BLOCK.

Table 9 shows that the model is significant with F-statistic value of (19.388) and sig of 0.000 , suggesting that the model is statistically valid. Because the value of the significance is 0.000 which is less than 0.05 , thus the conclusion is that the relationship between ownership structure, capital structure and ROA is general in statistically significant at a level below 0.05 .

Table 9

ANOVA Results for the Variables in Model 2

\begin{tabular}{|c|c|c|c|c|c|c|}
\hline \multicolumn{7}{|c|}{ ANOVA $^{a}$} \\
\hline & Model & Sum of Squares & Df & Mean Square & $\mathbf{F}$ & Sig. \\
\hline \multirow{3}{*}{2} & Regression & 0.685 & 7 & 0.098 & 19.388 & $0.000^{\mathrm{b}}$ \\
\hline & Residual & 2.101 & 416 & 0.005 & & \\
\hline & Total & 2.786 & 423 & & & \\
\hline
\end{tabular}

\footnotetext{
a Dependent variable: ROA, and

b Predictors: (Constant), INDUSTRY, FOREIGN, LEV, MNAGERAL, LNASSET, INST, BLOCK.
}

In other words there is a statistically significant linear dependence of the mean of ROA on ownership structure and capital structure was detected. This leads to the rejection of the second null hypothesis and concluding that there is a statistical significant impact of capital structure on the relationship between ownership structure and the performance of the shareholding companies listed in Amman Stock Exchange measured by ROA. However, the impact of the leverage on the performance measured by ROA as appears from table 10 is negative and insignificant because the regression coefficient is -0.048 and the significance is 0.286 . This conclusion is consistent with previous studies (Salehi \& Biglar, 2009; Adekunle, 2010) who argued that that a firm's capital structure surrogated by Debt Ratio, has a significant negative impact on 
the firm's financial performance. It is also congruent with (Sheikh et al., 2013) who found a negative relationship between leverage and performance. They argued that the acceptance of higher levels of leverage might limit the managers' ability to be creative and innovative and might negatively influence performance. However, it appears that the impact of leverage on performance depends on the type of ownership, therefore, we see that the relationship between the ownership and performance improved after entering the leverage in Model 2.

In order to test the sub-hypotheses of the second hypothesis Table 10 shows the regression coefficients for each type of ownership. The regression coefficient for institutional ownership after taking into account the effect of the capital structure is $(-0.034)$ in comparison with the coefficient before considering the effect of the capital structure (-0.102), and the significance value is (0.528), therefore the negative effect of the capital structure on the relationship between institutional ownership and ROA increased but still insignificant. Accordingly, we accept the first sub-null hypothesis and conclude that there is no significant statistical impact of the capital structure on the relationship between institutional ownership and performance measured by ROA.

\section{Table 10}

Regression Results for Model 2 and the Collinearity Statistics for the Independent Variables

\begin{tabular}{|c|c|c|c|c|c|c|c|}
\hline \multicolumn{8}{|c|}{ Coefficients $^{\mathrm{a}}$} \\
\hline \multirow[t]{2}{*}{ Model } & \multicolumn{2}{|c|}{$\begin{array}{c}\text { Unstandardized } \\
\text { Coefficients }\end{array}$} & \multirow{2}{*}{$\begin{array}{c}\begin{array}{c}\text { Standardized } \\
\text { Coefficients }\end{array} \\
\text { Beta }\end{array}$} & \multirow[t]{2}{*}{$\mathbf{t}$} & \multirow[t]{2}{*}{ Sig. } & \multicolumn{2}{|c|}{$\begin{array}{c}\text { Collinearity } \\
\text { Statistics }\end{array}$} \\
\hline & B & Std. Error & & & & Tolerance & VIF \\
\hline (Constant) & -0.417 & 0.048 & & -8.737 & 0.000 & & \\
\hline INST & -0.010 & 0.016 & -0.034 & -0.632 & 0.528 & 0.622 & 1.607 \\
\hline FOREIGN & -0.051 & 0.016 & -0.152 & -3.177 & 0.002 & 0.787 & 1.271 \\
\hline BLOCK & 0.030 & 0.024 & 0.081 & 1.251 & 0.212 & 0.430 & 2.328 \\
\hline MNAGERAL & -0.003 & 0.022 & -0.009 & -0.125 & 0.901 & 0.377 & 2.654 \\
\hline LNASSET & 0.029 & 0.003 & 0.531 & 10.044 & 0.000 & 0.647 & 1.545 \\
\hline LEV & -0.115 & 0.019 & -0.292 & -5.952 & 0.000 & 0.752 & 1.329 \\
\hline INDUSTRY & -0.008 & 0.007 & -0.048 & -1.068 & 0.286 & 0.911 & 1.098 \\
\hline
\end{tabular}

a Dependent variable: ROA.

The regression coefficient for the foreign ownership after taking the effect of the capital structure is $(-0.152)$ in comparison with the coefficient before considering the effect of the capital structure $(-0.137)$, and the significance value is $(0.002)$, therefore the effect of the capital structure on the relationship between the concentrated ownership and ROA is significant. Accordingly, we reject the second sub-null hypothesis and conclude that there is a negative and significant statistical impact of the capital structure on the relationship between foreign ownership and performance measured by ROA.

The regression coefficient for concentrated ownership after taking the effect of the capital structure is (0.081) in comparison with the coefficient before considering the effect of the capital structure (0.078), and the significance value is $(0.212)$, therefore the effect of the capital structure on the relationship between the concentrated ownership and ROA is insignificant. Accordingly, we accept the third sub-null hypothesis and conclude that there is no significant statistical impact of the capital structure on the relationship between institutional ownership and performance measured by ROA.

The regression coefficient for the managerial ownership after taking into account the effect of the capital structure is (-0.009) in comparison with the coefficient before 
considering the effect of the capital structure (0.094), and the significance value is (0.901), therefore the effect of the capital structure on the relationship between managerial ownership and ROA is negative and insignificant. Accordingly, we accept the fourth sub-null hypothesis and conclude that there is no significant statistical impact of the capital structure on the relationship between managerial ownership and performance measured by ROA.

\section{CONCLUSIONS AND RECOMMENDATIONS}

This study investigates the relationship between the ownership structure, capital structure and the performance of shareholding companies listed in the Amman Stock Exchange.

The study concluded that the relationship between ownership structure in general and the performance measured by ROA is positive and statistically significant. However, the results showed that the various types of ownership structure have different types of relationships with performance, that is, some of them have positive and others have negative relationship. More specifically, the results of the study revealed that there is a negative and insignificant statistical impact of institutional ownership on performance measured by ROA. The results also provide evidence that there is a negative and significant statistical impact of foreign ownership on performance measured by ROA. Additionally, the results revealed that the effect of each of the concentrated ownership and managerial ownership on performance measured by ROA is positive but insignificant.

Furthermore, the results revealed that there is a negative and significant statistical impact of leverage on performance. However, in general, the relationship between ownership structure, capital structure and ROA is statistically significant. Additionally, the financial leverage positively affects the relationship between ownership structure and firm's performance. However, on the one hand, the results showed that there is a negative and insignificant statistical impact of the capital structure on the relationship between institutional ownership and performance and on the relationship between managerial ownership and performance. On the other hand, the results showed that there is a negative and significant statistical impact of the capital structure on the relationship between foreign ownership and performance measured by ROA. Additionally, the results showed that there is a positive and insignificant statistical impact of the capital structure on the relationship between concentrated ownership and performance measured by ROA.

As appears from our results and the results of previous studies across countries all over the world, the relationship between ownership structure, capital structure and performance varies. This means that the relationship between these variables must be investigated within it is context, and the results must be interpreted within this context. That is, any type of ownership may give specific impact on corporate performance. Based on the discussion of the results above, we conclude that the findings of the study, provide us with evidence from a specific environment, a middle east country, to some extent, with specific economic, cultural and societal characteristics, therefore, we see that the results some times are consistent with previous research findings in some countries and are inconsistent with others.

Based on the findings of the study the researcher would recommend regulators in Jordan to take into consideration the environment-specific factors when developing corporate regulations and encourage concentrated and managerial ownership because they have positive impact on performance. Decision makers are recommended to be 
careful when considering the composition of capital structure and the leverage ratio. Additionally, policy makers are recommended to be careful when considering foreign investment in Jordanian market.

\section{REFERENCES}

Achchuthan, S., \& Kajananthan, R. (2013). Corporate governance practices and firm performance: Evidence from Sri Lanka. European Journal of Business \& Management, 5(1), 19-26.

Adekunle, O. A. (2010, October). Capital structure and firm performance: Evidence from Nigeria. European Journal of Economics, Finance \& Administrative Sciences, 25, $70-82$.

Al-Haddad, W. M., Alzurqan, S. T., \& Al_Sufy, F. J. (2011). The effect of corporate governance on the performance of Jordanian industrial companies: An empirical study on Amman stock exchange. International Journal of Humanities \& Social Science, 1(4), 55-69.

Al-Najjar, D. (2015). The effect of institutional ownership on firm performance: Evidence from Jordanian listed firms. International Journal of Economics \& Finance, 7(12), 97-105.

Asadi, A., \& Bahlevan, M. (2016). The relationship between ownership structure and firms' performance in Tehran stock exchange. Journal of Insurance \& Financial Management, 1(2), 62-76.

Barzegar, B., \& Babu, K. N. (2008, March). The effects of ownership structure on firm performance: Evidence from Iran. The Icfai Journal of Applied Finance, 14(3), 43-55.

Bathala, C., \& Rao, R. (1995). The determinants of board composition: An agency perspective. Managerial \& Decision Economics Journal, 16(1), 59-69.

Baysinger, B., \& Hoskisson, R. E. (1990). The composition of boards of directors and strategic control: Effects on corporate strategy. Academy of Management Review, 15(1), $72-87$.

Ben Ali, C., \& Lesage, C. (2016). Blockholders' ownership and audit fees: The impact of the corporate governance model. European Accounting Review, 25(2), 1-24.

Berger, A., \& Bonaccorsi di Patti, E. (2006). Capital structure and firm performance: A new approach to testing agency theory and an application to the banking industry. Journal of Banking \& Finance, 30(4), 1065-1102.

Berle, A., \& Means, G. (1932). The modern corporation and private property. New York: Macmillan, Harcourt, Brace, \& World.

Bjuggren, P. O., Eklund, J., \& Wiberg, D. (2007, October). Institutional ownership and the return on investments. Working Paper, 96, JIBS \& CESIS.

Boardman, A. E., Shapiro, D. M., \& Vining A. R., (1997). The role of agency costs in explaining the superior performance of foreign MNE subsidiaries. International Business Review, 6(3), 295-317.

Boroujeni, H. N., Noroozi, M., Nadem, M., \& Chadegani, A. A. (2013). The impact of capital structure and ownership structure on firm performance: A case study of Iranian companies. Research Journal of Applied Sciences, Engineering \& Technology, 6(22), 4265-4270.

Brailsford, T. J., Oliver, B. R., \& Pua, S. L. (2002). On the relation between ownership structure and capital structure. Accounting \& Finance, 24(1), 1-26.

Brenda, G. (2014). Ownership structure, performance and capital structure of Romanian firms. Internal Auditing \& Risk Management, Anul IX, 4(36), 1-9. 
Bushee, B. (1998). Institutional investors, long term investment and earnings management. Journal of Accounting Review, 55(15), 305-340.

Chari, A., Chen, W., \& Dominguez. (2009, March). Foreign ownership and firm performance: Emerging-market acquisitions in the United States. Working Paper, 14786, NBER.

Chen, J., Blenman, L., \& Chen, D. (2008). Does institutional ownership create values? New Zealand case. Quarterly Journal of Finance \& Accounting, 47(4), 109-132.

Chow, C. W. (1982). The demand for external auditing: Size, debt and ownership influences. The Accounting Review, 57(2), 272-291.

Chung, R., Firth, M., \& Kim, J. (2002). Institutional monitoring and opportunistic earnings management. Journal of Corporate Finance, 8(1), 29-48.

Cronqvist, H., \& Nilsson, M. (2003). Agency costs of controlling minority shareholders. The Journal of Financial \& Quantitative Analysis, 38(4), 695-719.

Demsetz, H. (1983). The structure of ownership and the theory of the firm. The Journal of Law \& Economics, 26(2), 375-390.

Demsetz, H., \& Lehn, K. (1985). The structure of corporate ownership: Causes and consequences. Journal of Political Economy, 93(6), 1155-1177.

Demsetz, H., \& Villalonga, B. (2001). Ownership structure and corporate performance. Journal of Corporate Finance, 7(3), 209-233.

Denis, D. K., \& McConnell, J. J. (2003). International corporate governance. Journal of Financial \& Quantitative Analysis, 38(1), 1-36.

Fama, E. F., \& Jensen, M. C. (1983). Separation of ownership and control. Journal of Law \& Economics, 26(2), 301-325.

Fan, J. P., \& Wong, T. J. (2005). Do external auditors perform a corporate governance role in emerging markets? Evidence from East Asia. Journal of accounting research, 43(1), 35-72.

Fazlzadeh, A., Hendi, A., \& Mahboubi, K. (2011). The examination of the effect of ownership structure on firm performance in listed firms of Tehran Stock Exchange based on the type of the industry. International Journal of Business \& Management, 6(3), 249-266.

Field, A. (2005). Discovering statistics using SPSS and sex, drugs and rock ' $n$ ' roll (2nd ed.). London, California, New Delhi: SAGE Publications.

Gedajlovic, E., Yoshikawa, Y., \& Hashimoto, M. (2005). Ownership structure, investment behaviour and firm performance in Japanese manufacturing industries. Organizational Studies, 26(1), 7-35.

Gillan, S. L., \& Starks, L. T. (2003). Corporate governance, corporate ownership, and the role of institutional investors: A global perspective. Journal of Applied Finance, 13(2), 4-22.

Gujarati, D. (2009). Basic econometrics (5 $5^{\text {th }}$ ed.). The McGraw-Hill Companies.

Gunduz, L., \& Tatoglu, E. (2003). A comparison of the financial characteristics of group affiliated and independent firms in Turkey. European Business Review, 15(1), 48-54.

Gurbuz, A. O., \& Aybars, A. (2010). The impact of foreign ownership on firm performance, evidence from an emerging market: Turkey. American Journal of Economics \& Business Administration, 2(4), 350-359.

Hair Jr, J. F., Black, J. W., Babin, B. J., \& Anderson, E. R. (2010). Multivariate data analysis (7th ed.). Edinburgh: Pearson Education Limited.

Hsu, H. (2013). The moderating effects of leverage and ownership structure on firm performance. South East Asia Journal of Contemporary Business, Economics \& Law, 2(1), 73-76. 
Hu, Y., \& Izumida, S. H. (2008). The relationship between ownership and performance: A review of theory and evidence. International Business Research, 1(4), 72-78.

Jaafar, A., \& El-Shawa, M. (2009). Ownership concentration, board characteristics and performance: Evidence from Jordan. Research in Accounting in Emerging Economies, 9, 73 - 95.

Jensen, M.C., \& Meckling, W. H. (1976). Theory of the Firm: Managerial behavior, agency costs and ownership structure. Journal of Financial Economics, 3(4), 305-60.

Jiang, P. (2004). The relationship between ownership structure and firm performance: An empirical analysis over Heilongjiang listed companies. Nature \& Science, 2(4), 87-92.

Kajananthan, R., \& Nimalthasan, P. (2013). Capital structure and its impact on firm performance: A study on Sri Lankan listed manufacturing companies. Merit Research Journal of Business \& Management, 1(2), 37-44.

Kapopoulos, P., \& Lazaretou, S. (2007). Corporate ownership structure and firm performance: Evidence from greek firms. Corporate Governance, 15(2), 144- 158.

Khamis, R., Hamdan, A. M., \& Elali, W. (2015). The relationship between ownership structure dimensions and corporate performance: Evidence from Bahrain. Australasian Accounting, Business \& Finance Journal, 9(4), 38-56.

Kim, W. S., \& Lyn, E. O. (1990). FDI theories and the performance of foreign multinationals operating in the US. Journal of International Business Studies (1 ${ }^{\text {st }}$ quarter), 21(1), 41-54.

King, M. R., \& Santor, E. (2007, July). Family values: Ownership structure, performance and capital structure of Canadian firms. Working Paper, 40, Bank of Canada. Retrieved from http://www.bankofcanada.ca.

Konings, J. (2001). The effects of foreign direct investment on domestic firms: Evidence from firm-level panel data in emerging economies. Economics of Transition, 9(3), 619-633.

Kordlor, A., Moradi, M., \& Skandar, H. (2010). The impact of institutional ownership type on the performance of listed companies in Tehran Stock Exchange. Journal of Accounting \& Auditing (2nd years), 26(8), 375-390.

Kumar, J. (2003). Does Ownership Structure Influence Firm Value? Evidence from India. Working Paper, Indira Gandhi Institute of Development Research, India. Retrieved from http://dx.doi.org/10.2139/ssrn.464521.

Leech, D., \& Leahy, J. (1991). Ownership structure, control type classifications and the performance of large British companies. Economic Journal, 101(409), 1418-1437.

Li, D., Moshirian, F., Nguyen, P., \& Tan, L. (2007). Managerial ownership and firm performance: Evidence from China's privatizations. Research in International Business \& Finance, 21(3), 396-413.

Mandac1, P. E., \& Gumus, G. K. (2010). Ownership concentration, managerial ownership and firm performance: Evidence from Turkey. SEE Journal, 5(1), 5766.

Margaritis, D., \& Psillaki, M. (2010). Capital structure, equity ownership and firm performance. Journal of Banking \& Finance, 34(3), 621-632.

Matanda, J. W., Oyugi, L., \& Lishenga, J. L. (2015). Institutional ownership and commercial performance in Kenya is there relationship. Research Journal of Finance \& Accounting, 6(16), 219-227.

Moghadam, M. D., \& Jafari, M. (2015). The role of financial leverage in the performance of companies listed in the stock exchange. Indian Journal of Natural Sciences, 5(30), 7402-7411. 
Morck, R., Wolfenzon, D., \& Yeung, B. (2005, September). Corporate governance, economic entrenchment and growth. Journal of Economic Literature, XLIII, 655-720.

Musallam, S. R. M. (2015). Relationships between ownership structures and corporate performance: Evidence from Malaysia. American Journal of Economics \& Business Administration, 2(4), 350-359,

Nadia, T. (2004). Ownership structure, board characteristics and firm profitability. Unpublished master's dissertation, Hashemite University, Jordan.

Nelson, S., \& Mohamed-Rusdi, N. (2015). Ownership structures influence on audit fee. Journal of Accounting in Emerging Economies, 5(4), 457 - 478.

Ongore, V. O. (2011). The relationship between ownership structure and firm performance: An empirical analysis of listed companies in Kenya. African Journal of Business Management, 5(6), 2120-2128.

Pallant, J. (2010). SPSS survival manual: A step by step guide to data analysis using SPSS (4th ed.). Australia: Allen and Unwin Book Publishers.

Perrini, F., Rossi, G., \& Rovetta, B. (2008). Does ownership structure affect performance? Evidence from the Italian market. Corporate Governance, 16(4), 312325.

Rahmani, A., Mashayekh, Sh., \& Parto Azam, M. (2010). The effect of ownership structure type on firm performance. Financial Accounting \& Auditing Research Review (3 $3^{\text {rd }}$ year), 9, 1-21.

Saleh, A. S., Halili, E., Zeitun, R., \& Salim, R. (2017). Global financial crisis, ownership structure and firm financial performance: An examination of listed firms in Australia. Studies in Economics \& Finance, 34(4), 447-465.

Salehi, M., \& Biglar, K. (2009). Study of the relationship between capital structure measures and performance: Evidence from Iran. Journal of Business \& Management, 4(1), 97-103.

Samiloglu, F., \& Ulas, U. (2010). The relationship between ownership structure and firm performance. The Journal of Accounting \& Finance, 46, 66-73.

Sheikh, N., Wang, Z., \& Khan, S. (2013). The impact of internal attributes of corporate governance on firm performance. International Journal of Commerce \& Management, 23(1), 38-55.

Slovin, M. B., \& Sushka, M. E. (1993). Ownership concentration, corporate control activity, and firm value: Evidence from the death of insider block holders. The Journal of Finance, 48(4), 1293-1322.

Thomsen, S., \& Pedersen, T. (2000). Ownership structure and economic performance in the largest European companies. Strategic Management Journal, 2(16), 689-705.

Viet, P. H. (2013). Foreign ownership and performance of listed firms: Evidence from an emerging economy. The Bulletin of the Graduate School of Commerce, Waseda University, 77, 285-310.

Wan, K. (1999). Do ownership and firm performance proxies matter? An empirical study of the relation of ownership structure and firm. Working Paper, University of Texas, Dallas.

$\mathrm{Xu}, \mathrm{X} .$, \& Wang, Y. (1999). Ownership structure, corporate governance in Chinese Stock Companies. China Economic Review, 10(1), 75-98.

Yuan, R., Xiao, J. Z., \& Zou, H. (2008). Mutual funds' ownership and firm performance: Evidence from China. Journal of Banking \& Finance, 32(8), 15521565.

Zhang, H. K. K. (2017). Ownership structure and firms performance: An empirical analysis of Chinese companies. Applied Economics \& Finance, 4(2), 57-64. 